\title{
Correlation at Different Ages Between Nitrogen, Green- and Dry-Matter Contents of Leaves, and Yield of Sugarcane Grown in Sand Culture
}

\author{
J. A. Bonnet, A. R. Riera, and J. Roldán ${ }^{1}$ \\ INTRODUCTION
}

Sugarcane and nitrogen play important roles in the agricultural economy of the Commonwealth of Puerto Rico. In 1950-51, nearly 45 percent of the total land in crops was devoted to growing sugarcane and 10,501,396 tons of cane were produced with a value of $\$ 106,379,000$. The total for 1953-54 was 10,879,000 tons with a value of about $\$ 104,000,000$. About 100,000 tons of nitrogen-bearing materials were imported in 1949-50, at a cost of $\$ 4,000,000$; this increased to 272,177 tons in $1950-51$, and the amount imported was 213,914 tons in 1953-54, costing about $\$ 8,000,000$.

Nitrogen imports doubled after 1949-50, while sugarcane production remained more or less constant. These figures imply an excessive application of nitrogen to sugarcane above that required for optimum growth. Data from two long-time experiments performed by the Soils Department of the Agricultural Experiment Station of the University of Puerto Rico, one in an acid soil in the humid area and one in a calcareous soil under irrigation in the arid area, have demonstrated that optimum yields of 12 consecutive crops of sugarcane, averaging 45 tons of cane per acre per crop, could be maintained with an annual application of 103 pounds of nitrogen per acre. Most farmers of Puerto Rico generally use two to three times that amount.

\section{REVIEW OF THE LITERATURE}

Clements $(5,6)^{2}$ in Hawaii, Bonnet (1), and Capó, et al.(4), in Puerto Rico, Innes (8) in Jamaica, and Halais (7) in Mauritius have discussed leaf nitrogen as a suitable index for the control of fertilizer applied to sugarcane. Rouillard (10) proposed the vegetative index, or the weight of 20 sugarcane leaves of the third rank, with the sampling done during the summer months, January to April, at the age of 8 to 10 months for virgins and 5 to 7 months for ratoons.

${ }^{1}$ Soil Chemist, Head, Soils Department, Associate Chemist in Charge Central Analytical Laboratory, and Assistant Chemist Soils Department, respectively, Agricultural Experiment Station, University of Puerto Rico, Río Piedras, P. R. The authors wish to thank Ishver S. Bangdiwala, Associate Statistician, Head of the Statistics Section, this Station, for his collaboration in the statistical interpretation of the data.

${ }^{2}$ Numbers in parentheses refer to Literature Cited p. 108-9. 


\section{OBJECTIVES}

A suitable index such as is proposed in this paper would be of great assistance to farmers if it enabled them, early in the life of their sugarcane crops, to determine whether additional nitrogen applications would be beneficial. For they could then correct nitrogen deficiencies affecting growth, and this would ultimately lead to large reductions in nitrogen costs.

In this work the low and high levels of nitrogen were known before planting time, because inert sand instead of soil was used as a substratum. Data are presented on correlation studies between the nitrogen content, the green and dry weights of the leaves, and the yield of sugarcane as a means of predicting relative yields when the nitrogen levels in the growth medium varied from deficiency to excess.

\section{EXPERIMENTAL PROCEDURE}

Twenty-eight concrete pits, each about 0.00077 of an acre in area, 7 feet 9 inches long, 4 feet 4 inches wide, and from 1 foot 9 inches to 1 foot 11 inches deep, provided with a drainage outlet, were constructed on the floor of a greenhouse with glass and ventilators at the roof; and open at the sides as shown in figure 1. A 3-inch layer of 800 pounds of thoroughly washed, noncalcareous, $1 / 2$-inch, river gravel was placed on the bottom of each pit; this was covered with 3,000 pounds of acid quartz sand.

The seven randomized treatments used were replicated four times and consisted of variable-unit concentrations of nitrogen, while the other nutrient elements were kept constant at maximum rates. The unit concentration used per pit was 0.03 pound of $\mathrm{N}, 0.015$ pound of $\mathrm{P}_{2} \mathrm{O}_{5}$, and 0.015 pound of $\mathrm{K}_{2} \mathrm{O}$.

The nitrogen was applied to the sand in the ratio of 90 parts of nitrate to 10 parts of ammonia, as proposed by Trealease and Trealease (11) for a medium around $\mathrm{pH}$ 6.0. The ammonia was added as ammonium sulfate, and the nitrate as tetrahydrated calcium nitrate. Seven different levels of nitrogen were studied, each containing 9 units of $\mathrm{P}_{2} \mathrm{O}_{5}$ and 13 units of $\mathrm{K}_{2} \mathrm{O}$ (see table 4, p. 105). The concentrations in parts per million of the other elements were; $\mathrm{Ca}, 165 ; \mathrm{S}, 124 ; \mathrm{Mg}$, 33; $\mathrm{Fe}, 13 ; \mathrm{Mn}, 1.07 ; \mathrm{Zn}, 0.83$; Co, $0.27 ; \mathrm{B}, 0.13$.

Sugarcane seeds of the M. 336 variety were disinfected before planting by immersion in hot water at $52^{\circ} \mathrm{C}$. for 20 minutes, and were then cut crosswise in one-eye node sections. These sections were planted on September 25, 1952, at a rate of one for each of four holes uniformly spaced in each pit, and were also germinated in a separate sand-bed to supply material for replanting. The plants were irrigated with rainwater when needed, after the drainage had been poured back.

Composite samples of the third, fourth, fifth, and sixth leaves, including 
blades and veins, were taken monthly at various growth intervals starting at 3 and ending at 15 months. The green weight of each of these samples was taken, and they were then prepared and analyzed for moisture and nitrogen by a method reported elsewhere $(2,9)$.

Arrowing started at 13 months. The crop was harvested on December 25,1953 , at the age of 15 months. Weights of cane, sugar, trash, and roots were recorded per treatment and the cane juice was analyzed for juice ex-



FIg. 1-Sugarcane variety M. 336, 9 months old and just before arrowing, growing in sand culture in the greenhouse used for the experiment.

traction and sugar content. The correlation between the nitrogen content, or the arc-tangent (3) of the nitrogen content of the sugarcane leaves, at the different monthly intervals, and the yield, or relative yield, of the cane were determined for the different nitrogen levels. The relative yields were based on percentages of the maximum yield. Similar correlations were also determined for the green and dry weights of the sugarcane leaves.

\section{RESULTS AND DISCUSSION}

The mean nitrogen contents and the green and dry weights of sugarcane leaves at the various monthly intervals are reported in tables 1 to 3 . The yields of cane, sugar, trash, and roots, the percentage of extracted sugar 


\section{JOURNAL OF AGRICULTURE OF UNIVERSTTY OF PUERTO RICO}

TABLE 1-Mean nitrogen contents at different crop ages of the leaves of sugarcane variety $M .336$ when grown in sand cultures at different nitrogen levels

\begin{tabular}{|c|c|c|c|c|c|c|c|c|c|c|c|c|c|}
\hline \multirow{2}{*}{$\begin{array}{l}\text { Units }{ }^{1} \text { of } N \\
\text { per pit }\end{array}$} & \multicolumn{13}{|c|}{ Percentage of nitrogen $(\mathrm{N})$ in months indicated- } \\
\hline & 3 & 4 & 5 & 6 & 7 & 8 & 9 & 10 & 11 & 12 & 13 & 14 & 15 \\
\hline 1.0 & 2.93 & 1.33 & 1.28 & 1.16 & 1.09 & 1.27 & 1.43 & 1.43 & 1.40 & 1.12 & 1.30 & 1.01 & 1.18 \\
\hline 2.5 & 3.07 & 1.95 & 1.74 & 1.52 & 1.16 & 1.22 & 1.51 & 1.49 & 1.37 & 1.14 & 1.39 & 1.19 & 1.15 \\
\hline 4.0 & 2.96 & 2.03 & 1.88 & 1.54 & 1.27 & 1.39 & 1.45 & 1.31 & 1.39 & .99 & 1.11 & .95 & 1.07 \\
\hline 5.5 & 2.92 & 1.91 & 1.90 & 1.82 & 1.53 & 1.43 & 1.71 & 1.51 & 1.38 & 1.11 & 1.25 & 1.08 & 1.03 \\
\hline 7.0 & 3.03 & 1.99 & 1.98 & 1.69 & 1.70 & 1.60 & 1.78 & 1.61 & 1.39 & 1.20 & 1.32 & 1.19 & 1.31 \\
\hline 8.5 & 3.00 & 2.12 & 2.05 & 1.92 & 1.69 & 1.75 & 1.79 & 1.64 & 1.53 & 1.25 & 1.39 & 1.29 & 1.20 \\
\hline 10.0 & 3.10 & 2.14 & 2.00 & 1.91 & 1.82 & 1.80 & 1.92 & 1.68 & 1.65 & 1.35 & 1.47 & 1.28 & 1.29 \\
\hline
\end{tabular}

${ }^{1}$ One unit is equal to $0.03 \mathrm{lb}$. of $\mathrm{N}$.

TABLE 2.-Mean green weights at different crop ages of the third, fourth, fifth, and sixth leaves of sugarcane variety $M .336$ when grown in sand cultures at different nitrogen levels

\begin{tabular}{l|c|c|c|c|c|c|c|c|c|c|c|c|c}
\hline $\begin{array}{c}\text { Units1 of N } \\
\text { per pit }\end{array}$ & \multicolumn{10}{|c|}{ Green weight in grams in months indicated- } \\
\cline { 3 - 13 } & $\mathbf{3}$ & 4 & $\mathbf{5}$ & 6 & 7 & 8 & 9 & 10 & 11 & 12 & 13 & 14 & 15 \\
\hline 1.0 & 148 & 178 & 184 & 178 & 213 & 196 & 171 & 194 & 110 & 164 & 120 & 100 & 105 \\
2.5 & 124 & 171 & 200 & 202 & 250 & 212 & 186 & 211 & 108 & 199 & 116 & 115 & 129 \\
4.0 & 130 & 174 & 205 & 219 & 235 & 233 & 233 & 227 & 130 & 208 & 146 & 104 & 123 \\
5.5 & 121 & 184 & 202 & 224 & 270 & 257 & 269 & 236 & 146 & 212 & 135 & 122 & 127 \\
7.0 & 136 & 190 & 201 & 223 & 288 & 249 & 292 & 281 & 136 & 245 & 151 & 153 & 165 \\
8.5 & 104 & 155 & 211 & 230 & 312 & 286 & 300 & 292 & 126 & 239 & 174 & 152 & 139 \\
10.0 & 144 & 172 & 207 & 219 & 315 & 267 & 295 & 284 & 137 & 253 & 199 & 136 & 166 \\
\hline
\end{tabular}

1 One unit is equal to $0.03 \mathrm{lb}$. of $\mathrm{N}$.

TABLE 3.-Mean dry weights at different crop ages of the third, fourth, fifth, and sixth leaves of sugarcane variety $M .336$ when grown in sand cultures at different nitrogen levels

\begin{tabular}{c|c|c|c|c|c|c|c|c|c|c|c|c|c}
\hline $\begin{array}{c}\text { Units } \text { of } N \\
\text { per pit }\end{array}$ & \multicolumn{10}{|c}{ Dry weight in grams in months indicated- } \\
\cline { 2 - 11 } & 3 & 4 & 5 & 6 & 7 & 8 & 9 & 10 & 11 & 12 & 13 & 14 & 15 \\
\hline 1.0 & 29 & 44 & 49 & 50 & 62 & 62 & 51 & 48 & 31 & 45 & 34 & 29 & 32 \\
2.5 & 25 & 41 & 49 & 54 & 73 & 66 & 55 & 52 & 30 & 55 & 32 & 34 & 38 \\
4.0 & 27 & 42 & 49 & 59 & 68 & 72 & 69 & 59 & 36 & 61 & 43 & 31 & 36 \\
$\mathbf{5 . 5}$ & 24 & 45 & 51 & 60 & 74 & 76 & 76 & 60 & 41 & 65 & 39 & 36 & 39 \\
7.0 & 28 & 47 & 51 & 60 & 78 & 73 & 79 & 70 & 37 & 69 & 43 & 43 & 48 \\
8.5 & 22 & 39 & 51 & 60 & 82 & 79 & 81 & 73 & 35 & 67 & 49 & 44 & 45 \\
10.1 & 30 & 41 & 50 & 59 & 85 & 74 & 78 & 70 & 38 & 70 & 55 & 39 & 49 \\
\hline
\end{tabular}

${ }^{1}$ One unit is equal to $0.03 \mathrm{lb}$. of $\mathrm{N}$. 
in the cane, and the least significant yield difference between mean treatments are reported for the various nitrogen treatments in table 4 . There were significant responses at the 1-percent level to nitrogen in the yields of cane, sugar, trash, and roots.

The percentages of variation explained by correlations between nitrogen, green or dry weights of the third, fourth, fifth, and sixth leaves of the cane, obtained at different ages of the cane, and yields, are reported in table 5, and the coefficients of variability in table 6 . The significance of the correlation of the corresponding yield estimate was about the same for all ages between arc-tan nitrogen (3) and relative yield, and between nitrogen per-

TABLE 4.-Mean cane, sugar, trash, and root yield, and percentage sugar content of sugarcane variety $M .336$, with least significant differences between treatment means, when grown in sand cultures in pits at different nitrogen levels

\begin{tabular}{|c|c|c|c|c|c|c|c|c|}
\hline \multirow{2}{*}{$\begin{array}{c}\text { Treatment } \\
\text { No. }\end{array}$} & \multicolumn{3}{|c|}{ Units' per pit of - } & \multicolumn{4}{|c|}{ Mean crop yield in tons per acre of- } & \multirow{2}{*}{$\begin{array}{l}\text { Percentage of } \\
\text { sugar in cane }\end{array}$} \\
\hline & $\mathrm{N}$ & $\mathrm{P}_{2} \mathrm{O}_{5}$ & $\mathrm{~K}_{2} \mathrm{O}$ & Cane & Sugar & Trash & Roots & \\
\hline 1 & 1.0 & 9 & 13 & 20.0 & 2.1 & 5.8 & 4.0 & 10.3 \\
\hline 2 & 2.5 & 9 & 13 & 27.8 & 3.1 & 8.1 & 5.9 & 11.2 \\
\hline 3 & 4.0 & 9 & 13 & 50.1 & 5.9 & 11.9 & 8.4 & 11.9 \\
\hline 4 & 5.5 & 9 & 13 & 62.8 & 8.3 & 13.8 & 7.5 & 13.1 \\
\hline $\mathbf{5}$ & 7.0 & 9 & 13 & 73.8 & 10.0 & 16.1 & 8.1 & 13.7 \\
\hline 6 & 8.5 & 9 & 13 & 81.3 & 11.0 & 19.0 & 7.7 & 13.5 \\
\hline 7 & 10.0 & 9 & 13 & 83.1 & 10.7 & 19.0 & 7.3 & 12.9 \\
\hline \multicolumn{9}{|c|}{ L.S.D. between treatment means: } \\
\hline \multicolumn{4}{|c|}{ 1-percent point } & 13.2 & 1.4 & 4.0 & 3.3 & 1.9 \\
\hline \multicolumn{4}{|c|}{ 5-percent point } & 9.6 & 1.0 & 2.9 & 2.4 & 1.4 \\
\hline
\end{tabular}

${ }^{1}$ One unit equals $0.03 \mathrm{Ib}$. of $\mathrm{N}$ and $0.015 \mathrm{lb}$. of $\mathrm{P}_{2} \mathrm{O}_{5}$ or $\mathrm{K}_{2} \mathrm{O}$.

centage and yield of cane; so also were the corresponding coefficients of variability. This similarity in the pattern of significance of correlations may be attributed to the low values of leaf-nitrogen percentage (range 0.95 to 3.10 , table 1) where the tangent curve is more or less linear.

The significance of correlation and coefficients of variability was about the same between green weight or dry weight and yield of cane, but a higher correlation was obtained by the green weight at 6 months and by the dry weight at 15 .

The correlation between leaf-nitrogen percentage and cane yield was not significant at ages of $3,11,12,13$, and 15 months; it was significant at the 5-percent level at 10 and 14 months, and at the 1-percent level at 4, 5, 6, 7,8 , and 9 months. The percentage of variation explained for the highest significant correlations between these values varied from 26 to 61 , and the 
coefficients of variability from 27 to 38 . The highest variation explained and the lowest coefficient of variability were obtained when the cane was

TABLE 5.-Percentage of variation explained by correlation of the yield estimates obtained at different ages of the cane ${ }^{1}$

\begin{tabular}{c|c|c|c|c}
\hline $\begin{array}{c}\text { Cane age } \\
\text { (months) }\end{array}$ & $\begin{array}{c}\text { Leaf arc-tan } N \text { and } \\
\text { relative yield }\end{array}$ & $\begin{array}{c}\text { Leaf } N \text { percentage } \\
\text { and cane yield }\end{array}$ & $\begin{array}{c}\text { Green weight and } \\
\text { cane yield }\end{array}$ & $\begin{array}{c}\text { Dry weight and } \\
\text { cane yield }\end{array}$ \\
\cline { 2 - 3 } 3 & 1 & 3 & 0 & 0 \\
4 & $38^{* *}$ & $36^{* *}$ & 3 & 8 \\
5 & $32^{* *}$ & $28^{* *}$ & 11 & 4 \\
6 & $32^{* *}$ & $26^{* *}$ & $28^{* *}$ & $22^{*}$ \\
7 & $65^{* *}$ & $61^{* *}$ & $39^{* *}$ & $37^{* *}$ \\
8 & $52^{* *}$ & $50^{* *}$ & $56^{* *}$ & $28^{* *}$ \\
9 & $33^{* *}$ & $33^{* *}$ & $79^{* *}$ & $80^{* *}$ \\
10 & $14^{*}$ & $15^{*}$ & $25^{* *}$ & $24^{* *}$ \\
11 & 8 & 8 & $16^{*}$ & $18^{*}$ \\
12 & 8 & 10 & $38^{* *}$ & $42^{* *}$ \\
13 & 0 & 0 & $46^{* *}$ & $49^{* *}$ \\
14 & $23^{*}$ & $22^{*}$ & $14^{*}$ & $16^{*}$ \\
15 & 4 & 4 & 11 & $16^{*}$ \\
\hline
\end{tabular}

$1 *$ Significant at 5 percent; ** significant at 1 percent.

TABLE 6.-Coefficients of variability of the yield estimates obtained at different ages of the cane

\begin{tabular}{c|c|c|c|c}
\hline $\begin{array}{c}\text { Cane age } \\
\text { (months) }\end{array}$ & $\begin{array}{c}\text { Leaf arc-tan N and } \\
\text { relative yield }\end{array}$ & $\begin{array}{c}\text { Leaf N percentage } \\
\text { and cane yield }\end{array}$ & $\begin{array}{c}\text { Green weight and } \\
\text { cane yield }\end{array}$ & $\begin{array}{c}\text { Dry weight and } \\
\text { cane yield }\end{array}$ \\
\cline { 1 - 2 } \cline { 1 - 1 } 3 & 44 & 44 & 44 & 44 \\
4 & 35 & 35 & 44 & 42 \\
5 & 36 & 37 & 42 & 42 \\
6 & 37 & 38 & 38 & 39 \\
7 & 26 & 27 & 35 & 35 \\
8 & 31 & 31 & 30 & 38 \\
9 & 36 & 36 & 21 & 20 \\
10 & 41 & 41 & 38 & 39 \\
11 & 42 & 43 & 41 & 40 \\
12 & 42 & 42 & 35 & 34 \\
13 & 44 & 44 & 33 & 32 \\
14 & 39 & 39 & 41 & 41 \\
15 & 43 & 44 & 42 & 41 \\
\hline
\end{tabular}

7 months old. The coefficient of correlation for 7 months was 0.78 for leaf nitrogen and cane yield and 0.81 for arc-tan nitrogen and relative yield, and the regression equations obtained were:

(Yield of cane in tons/acre) $=63.021$ (leaf $\mathrm{N}$ in percentage) -35.26

(Relative yield of cane) $=3.567$ (arc-tan $\mathrm{N}$ in percentage) -136.32 
The correlation between green weight and yield of cane was not significant at the ages of $3,4,5$, and 15 months; was significant at the 5-percent level at the ages of 11 and 14 months; and significant at the 1-percent level at the ages of $6,7,8,9,10,12$, and 13 months. Similar results were obtained with dry weight, except that the correlations at 6 and 15 months were significant at the 5-percent level. The percentages of variation explained for the highest significant correlations between green or dry weights and cane yields varied from 28 to 80 percent and the coefficients of variability between 20 and 39 percent. The highest variation explained and the lowest coefficient of variability were obtained when the cane was 9 months old.

The coefficient of correlation for 9 months was 0.89 for either green or dry weight and cane yield. The respective regression equations for green and dry weights were:

(Yield of cane in tons/acre) $=0.394$ (green weight of leaf in grams) -41.24 (Yield of cane in tons/acre) $=1.767$ (dry weight of leaf in grams) -66.53

\section{CONCLUSIONS}

The above correlation analyses indicate that the percentage nitrogen content of the third, fourth, fifth, and sixth leaves of sugarcane can be used as an index to predict the yield of cane almost as precisely as the arc-tangent of the nitrogen percentage.

The green and dry weights of these leaves can also be used to predict the yield.

The age of the plant must be taken into consideration for prediction of the yield. Correlations with nitrogen were significant at all ages between 4 to 10 months, and of green or dry weights between 6 to 14 months, for the M. 336 cane variety grown in sand cultures at different nitrogen levels.

\section{SUMMARY}

Sugarcane variety M. 336 was grown in sand cultures in 28 pits under cover to study the effect of increasing levels of nitrogen on crop yield and the correlation between the nitrogen, the green- or dry-matter contents, and crop yield. Seven increments of nitrogen, replicated four times, were studied with other nutrients and water at optimum levels.

The yield in tons per acre varied as follows: Cane, 20.0 to 83.1; sugar, 2.1 to 11.0 ; trash, 5.8 to 19.0 ; roots, 4.0 to 8.4 .

The sugar in the cane varied from 10.3 to 13.7 percent when the crop was harvested at the age of 15 months. There were significant responses to nitrogen at the 1-percent level in the yields of cane, sugar, trash, and roots.

The nitrogen content of the third, fourth, fifth, and sixth leaves varied from 0.95 to 3.10 percent when the cane was between 3 and 15 months old; the green weight of these four leaves varied from 100 to $315 \mathrm{gm}$. and their dry weight from 22 to $85 \mathrm{gm}$. 
Results indicate that nitrogen, and the green- or dry-matter contents of the cane leaves can be used to predict relative crop yields at specific crop ages. This is illustrated with three formulas derived from the data.

\section{RESUMEN}

En el experimento que se informa se sembró caña de azúcar, variedad M. 336, en 28 lisímetros de concreto, bajo techo, que contenían arena como substrato. El objetivo era estudiar el efecto del aumento de siete concentraciones variables de nitrógeno en el rendimiento, y la correlación entre el tonelaje y los contenidos de nitrógeno, materia verde, y materia seca, respectivamente, de las hojas de caña, a diferentes edades. La caña se abonó con cantidades suficientes de fósforo, potasio, y elementos menores; se le aplicó agua periódicamente. Las aguas filtrantes se devolvían a los lisímetros.

Los rendimientos de la cosecha a los 15 meses, en toneladas por acre, variaron como sigue: Caña, 20.0 á 83.1; azúcar, 2.1 á 11.0; paja, 5.8 á 19.0; y raíces, 4.0 á 8.4 .

$\mathrm{El}$ azúcar en la caña varió de 10.3 á 13.7 por ciento. Hubo respuestas significativas en cuanto al nitrógeno, al nivel del 1 por ciento, en los rendimientos de caña, azúcar, paja, y raíces.

Los contenidos de nitrógeno de las hojas tercera, cuarta, quinta y sexta variaron de 0.95 á 3.10 por ciento entre las edades de 3 y 15 meses; su peso verde varió de 100 á 315 gramos y el peso seco de 22 á 85 gramos.

Los resultados obtenidos indican que los contenidos de nitrógeno, de las hojas analizadas, a las edades entre 4 y 9 meses, se pueden usar como índices para predecir los rendimientos de la caña de azúcar. También pueden usarse como indices de predicción los pesos verdes y secos de las hojas entre los 6 y 13 meses.

Los datos obtenidos con nitrógeno dieron la correlación más alta, a los 7 meses, y los de materia verde o seca, a los 9 meses. Las cuatro fórmulas derivadas, a estas respectivas edades, donde $Y$ expresa el rendimiento de caña en toneladas por acre, fueron las siguiente:

$$
\begin{aligned}
& Y=63.021 \text { (N por ciento en la hoja) }-35.26 \\
& Y=0.394 \text { (peso verde de la hoja en gramos) }-41.24 \\
& Y=1.767 \text { (peso seco de la hoja en gramos) }-66.53
\end{aligned}
$$

\section{LITERATURE CITED}

1. Bonnet, J. A., Diagnóstico foliar para caña de azúcar, Caña y Azúcar, Revista Técnica Bilingüe, Organo oficial de la Asociación de Técnicos Azucareros de Puerto Rico, 2 (4) 7-13, Julio-Agosto 1953.

2. Bonnet, J. A., Riera, A., Roldán, J., y Ascorbe, F. J., Métodos para determinaciones de nitrógeno, fósforo y potasio total usados para análisis foliar en el 
Departamento de Suelos de la Estación Experimental Agrícola de la Universidad de Puerto Rico, A mimeographed paper written in Spanish and presented to the Annual Meeting of the Association of Sugar Cane Technologists, 12 pp., Jan. 20, 1951.

3. Capó, B. G. and Samuels, G., The development of a mathematical concept to interpret the relation between plant composition and crop yield, J. Agr. Univ. P. R. 37 (4) 249-64 1953.

4. Capó, B. G., Samuels, G., Landrau, Jr., P., Alers Alers, S., and Riera, A., The method of foliar diagnosis as applied to sugarcane, Agr. Exp. Sta. Univ. P. R. Bul. 123, 47 pp., Feb. 1955.

5. Clements, H. F., Crop logging sugarcane in Hawaii, Better Crops with Plant Food 32 (9) 11-8, 45-8, Nov. 1948, The American Potash Institute, Inc., 1155 16 St. N. W., Washington, D.C.

6. — Crop logging of sugarcane, principles and practices, Paper 13, Section Agriculture (Agronomy and Soils) Eighth Int. Sugar Cane Techs. Congress, Barbados, B. W. I., Apr. 1953.

7. Halais, P., Fumure et irrigation des cultures industrielles de cannes á sucre d' aprés les indicés foliares, (CS 13), IX Congresso Internazionale Industrie Agrarie Roma, 27 maggio-1 giugno 1952.

8. Innes, R. F., Plant analysis in relation to the nutrition of sugarcane in Jamaica, Proc. B. W. I. Sugar Tech. Conference, Barbados, 1948.

9. Riera, A. Part II, The chemical analysis of sugarcane leaf samples, Bul. 123, Agr. Expt. Sta. Univ. P. R., pp. 23-32, Feb. 1955.

10. Rouillard, G., Relation between vegetative index and weight of sugar per acre, pp. 317-20, Proc. Eighth Congress Int. Soc. Sugar Cane Techs., B. W. I., 1953.

11. Trealease, S. F., and Trealease, Helen, M., Changes in hydrogen-ion concentration of culture solutions containing nitrate and ammonium nitrogen, Amer. $J$. Bot. 22 (5) 520-42, 1935. 